\title{
The Effect of Small-Scale Dairy Farming in Enhancing Sustainable Food Security for Farmers and their Households in Murang'a East Sub-County, Murang'a County.
}

\author{
John Miano Mwangi'; Dr Charles N. Mogote ${ }^{2}$ \\ 1.2 Mount Kenya University, Kenya \\ Main author email: johnmiano2@gmail.com
}

\begin{abstract}
The study sought to investigate the effect of small-scale dairy farming in enhancing sustainable food security for farmers and their households in Murang'a East Sub-County, Murang'a County. The paper applied descriptive research design and quantitative research technique for the methodology. Besides, the investigation used a sample size computed from a populace size of small-scale dairy farmers in Gaturi, Township and Mbiri Wards (lower Kiharu Constituency), Murang'a East Sub-County, approximated to be 45,000 Km². The sample size comprised of 385 respondents selected through stratified sampling aiming at the equal representation of the three wards. Out of the selected 385 individuals, only 297 respondents were effective participants in the study. The rest did not give feedback or were nonresponsive. The data analysis used descriptive statistics through the Microsoft Excel data analysis tools to develop distribution tables, frequencies, percentages, charts, and measures of central tendency. Data collection instruments included questionnaires, interviews and observation. The study also conducted a pre-test and analysis to ensure validity, accuracy, and reliability of instruments applied. Data collection process involved getting permits and necessary approvals. The study concluded that the study concludes that small-scale dairy farming has an effect in multiple ways on food security within the county. The effect is the provision of milk to the farmers for consumption as food. The study recommends that county government should invest in research activities that would enhance dairy farming practices. Such research activities may include those on the market, diseases, animal feeds, and value addition to dairy produce.
\end{abstract}

Key Terms: Small-Scale Dairy Farming, Sustainable Food Security, Households.

$$
* * *
$$

\section{How to cite this article in APA ( $6^{\text {th }}$ Edition)}

Mwangi, J.M. \& Mogote, C. N. (2020). The Effect of Small-Scale Dairy Farming in Enhancing Sustainable Food Security for Farmers and their Households in Murang'a East Sub-County, Murang'a

County. Editon Cons. J. Arts., Humanit. S. Stud., 2(01), 206-211. Doi: 10.51317/ecjahss.v2i1.185 $* * *$ 


\section{Editon Consortium Journal of Arts, Humanities and Social Studies (ECJAHSS)}

Doi: $10.51317 /$ ecjahss.v2i1.185

Volume: 02 Issue: 01 | Dec-2020

ISSN: $2663-8525$

Received: 02.12.2020; Accepted 05.12.2020; Published: 25.12.2020 at www.editoncpublishing.org

Mwangi, J.M., et al., Editon Cons. J. Arts., Humanit. S. Stud., Double -Blind Peer Reviewed Journal

\section{Introduction}

According to FAO (2019), dairy farming contributes to improved livelihood by providing food. It plays a role in the contribution of more than a third of the GDP of the developing countries by contributing to improving food security, income, access to education, and reduces the threats of diseases (FAO, 2019). Estimates show that 3.1 billion of the world's 7.5 billion people live on less than 1 USD per day (World Bank, 2019). In the $21^{\text {st }}$ century, there have been concerted efforts towards the elimination of this challenge. This has seen governments in the region adopt various measures including policy changes and elimination of political instability in a bid to enhance investments and boost the economy by developing strategies on how to improve food security, improve income, access to quality education and health (Omolo, 2012).

Kenya's small-scale farming contributes 14 per cent of the gross domestic product (GDP) (Nyoike, 2015). It plays a significant part in ensuring food security, which is the key precept of livelihood. This it does for both the farmers as well as all the other secondary contributors in the milk supply chain. Dairy production sector has been hugely dominated by small-scale farmers, with control of about 98 per cent of the aggregate dairy cattle (Clay, et al., 2019). The number of small-scale dairy farmers is predicted to be roughly 1.5 million households.

Small Scale Dairy farming is an important sector in Kenya's economy, producing more than half of the total milk in Kenya. However, residents' of Murang'a East Sub-County, Murang'a County are experiencing challenges of food insecurity, poor income, and poor education and health standards like many others in rural Kenya.

Before the liberalization/structural adjustments era of the 1990's, coffee and small-scale dairy farming were major sources of small-scale farmers' livelihoods in Murang'a East
Sub-County, Murang'a County (Richards, et al., 2015). Farmers abandoned coffee farming due to poor and unpredictable pay, forcing them to concentrate on smallscale dairy farming.

The previous study on the small-scale dairy sector has focused on socio-economic aspects of livestock development. Rademaker et al. (2016) evaluated the performance of smallholder dairy farmers in Murang'a by evaluating the impact of technical interventions in the dairy enterprise. Murang'a county government has focused on improving small-scale dairy farmers through the increase of production and marketing as a viable intervention but has not looked into the impact of small-scale dairy farming in improving the livelihoods of households particularly on food security, income, education, and health (Rademaker, et al., 2016). This study, therefore, sought to investigate the effect of small-scale dairy farming in enhancing sustainable food security for farmers and their households in Murang'a East Sub-County, Murang'a County.

\section{LITERATURE REVIEW}

\section{Significance of Small-Scale Dairy Farming}

Small-scale dairy farming in Kenya emerged since the early years of colonialism, which was rarely for economic purposes. Those who engaged in it did so with the intention of using the produce for their household needs. Large-scale farmers in the country who included the white settlers were farming in Central Kenya highlands and Rift Valley region. It is through this group that the country had seen the creation of the first dairy processor in the country (Bruno, et al., 2015). After the country attained independence in 1964, the plant was converted into a government parastatal with the clear mandate of revolutionizing dairy farming among the small-scale dairy farmers all over Kenya. The approach was in line with the

\footnotetext{
(c) 2020, Editon Consortium Publishing | This work is licensed under a Creative Commons Attribution-Non Commercial-Share

Alike 4.0 International License. | Website: www.editoncpublishing.org
} 


\section{Editon Consortium Journal of Arts, Humanities and Social Studies (ECJAHSS)}

Doi: $10.51317 /$ ecjahss.v2i1.185

Volume: 02 Issue: 01 | Dec-2020

ISSN: $2663-8525$

Received: 02.12.2020; Accepted 05.12.2020; Published: 25.12.2020 at www.editoncpublishing.org

Mwangi, J.M., et al., Editon Cons. J. Arts., Humanit. S. Stud., Double -Blind Peer Reviewed Journal

government's intention of empowering the communities living in rural areas and improve livelihood.

Since then, the parastatal has worked to ensure the enhancement of the sector through the purchase of raw milk from small-scale dairy farmers and then processing it into various products. In fact, it had become a role model for other parastatals in the agricultural sector due to the high returns to farmers and its contribution to both household and national economic growth. Majority of households in rural and sometimes urban areas were rearing cows with the objective of increasing their net family net family income (Omolo, 2012).

Due to challenges, it collapsed, leaving only a few private milk processing plants that could not buy the supply and this led to most small-scale dairy farmers abandoning dairy farming (Nyarongi, 2003). During this period, economic and historic indicators have shown that most of the households that survived on dairy farming were experiencing financial difficulty and were gradually being pushed to poverty.

It has been established that for most households that abandoned dairy farming without having another source of income, do have challenges in malnutrition as well as eating a balanced diet since they could not purchase milk for domestic consumption leading to poor livelihood. (Wafula N: 2012). Due to this, the national government revived the already collapsed Kenya Co-operative Creameries (KCC) and renamed it New Kenya Co-operative Creameries (NKCC). The processing plant was less dependent on raw milk from large ranches, and more concerned with the enhancement of milk productivity from small-scale dairy farmers (East Africa Dairy Development Project, 2013). The approach was to provide a way of livelihood for thousands of households that were interested in small-scale dairy farming.

\section{Small-Scale Dairy farmers Cooperative Movement}

In the contemporary world and especially in developing nations, many people feel powerless in enhancing their financial capabilities. As such, the role played by cooperative movements has been significant in offering them a viable, strong, and vibrant economic alternative. The formation of cooperatives is characterized by the need of individuals to address mutual needs that affect them. In Kenya, the role of cooperative movement has been more noticeable among farmers (Njiru, 2015). This is more so in cooperative dairy societies.

In achieving the intended goals, small-scale dairy farmers cooperative movements have been effective in capacity building, which entails an organized process that offers systematic inputs to members hence leading to the acquisition of skills, practical knowledge, and positive attitudes (Bello, 2010). They develop credit facilities such as SACCOs, thus offering dairy farmers an opportunity to increase investments in the farming activity as well as respond to other financial challenges that affect their households.

Cooperatives also offers dairy farmers the opportunity to have their raw milk processed into finished products that would fetch higher profits in the market and a joint platform for marketing of the end product (Bello, 2010). Besides, an abstract from Ministry of Agriculture's National Dairy Development Policy (2013) indicates that the cooperative movement has been a core contributor to the development of the dairy sector in the Republic of Kenya and individual growth (Kenya Dairy Board, 2013). This enables farmers to get earnings for their daily upkeep in food security, income, access to education and better health.

Importance of Small-Scale Dairy Farming in Food Security The improvement of food security remains the largest concern among households in small-scale dairy farming;

208 


\section{Editon Consortium Journal of Arts, Humanities and Social Studies (ECJAHSS)}

Doi: $10.51317 /$ ecjahss.v2i1.185

Volume: 02 Issue: 01 | Dec-2020

ISSN: $2663-8525$

Received: 02.12.2020; Accepted 05.12.2020; Published: 25.12.2020 at www.editoncpublishing.org

Mwangi, J.M., et al., Editon Cons. J. Arts., Humanit. S. Stud., Double -Blind Peer Reviewed Journal

hence; its performance has a significant effect of livelihood levels. Agriculture itself accounts for about half (46.2\%) of GDP and about 50 per cent of export, while agricultural products accounts for about 70 per cent of rural household income (Kibiego, et al., 2015). Majority in rural areas depend on agriculture for their livelihood. This implies that improvement in farm incomes of the majority of the rural population is a precondition for the improvement of livelihood. Secondly, food insecurity is the manifestation of poverty. It is estimated that close to 42 per cent of households regularly have inadequate food (URT, 2001).

According to $\mathrm{FAO}$, livestock rearing has a notable role in guaranteeing food security as it assists in alleviating seasonal food available in a number of ways. Raw milk production is seasonal and could be processed when there is a surplus in the market. The key dairy produce consumable in the future from processed milk include butter, powdered milk, cheese, as well as curd (FAO, 2019). Similarly, when dairy cattle gets old and less productive, it can be slaughtered for immediate or future consumption. In modern times, technology is available for meat preservation purposes. At a rural home, there are also a number of benefits derived from rearing dairy cattle, including milk for home consumption, manure for crops, and biogas for cooking purposes among other uses. Manure from dairy cattle is also used, as noted earlier, in improving soil fertility and organic fertilizer, thus improving crop production.

\section{RESULTS}

\section{Food Security and Small Scale Dairy Farming}

From the findings, 87 per cent of the respondents made it clear that households with dairy cattle in the rural areas of Murang'a East Sub-County had meals more often than those that did not rear dairy cattle. In view of this, they can afford a balanced diet over a long period. Hence, a sustainable source of food, whether directly or indirectly, to small-scale dairy farmers. Small-scale dairy farmers indicated they used income from milk sales to purchase foodstuffs and animal manure to grow crops. Small-scale dairy farmers who participated in the research exercise indicated that small-scale dairy farming had an impact on the availability of food in their household as well as in the local community. This was largely through the sale of milk and consumption of milk considered a highly nutritious commodity and an essential part of a healthy diet. A simpler representation of the data in this category indicated that 87 per cent of dairy farmers saw the input of dairy farming in enhancing food security within their households as well as for the community while 13 per cent did not. This was because they had other sources of income, which they relied on for their livelihoods.

With enhanced measures on small-scale dairy farming productivity among small-scale farmers, food security in the sub-county could improve by approximately 70 per cent. The figures have been well represented in form of a chart in figure 2 below. This came in several ways including consumption of milk directly for the family, use of dairy revenues to buy food, as well as utilization of cow dung manure in boosting food production. This became a clear indicator of how well dairy farming was providing food security to the farmers. The agricultural extension officers noted that courtesy of dairy farming, many households were able to access food supplies. The county government livestock officers made recognition of this in their responses to the interview schedule, identifying this as a core driver to pushing the county government to have a dairy cow for all poor households as a way of ensuring they can feed themselves. 


\section{Editon Consortium Journal of Arts, Humanities and Social Studies (ECJAHSS)}

Doi: 10.51317/ecjahss.v2i1.185

Volume: 02 Issue: 01 | Dec-2020

ISSN: $2663-8525$

Received: 02.12.2020; Accepted 05.12.2020; Published: 25.12.2020 at www.editoncpublishing.org

Mwangi, J.M., et al., Editon Cons. J. Arts., Humanit. S. Stud., Double-Blind Peer Reviewed Journal

\section{Dairy Farming Contribution to Food Security for Households}

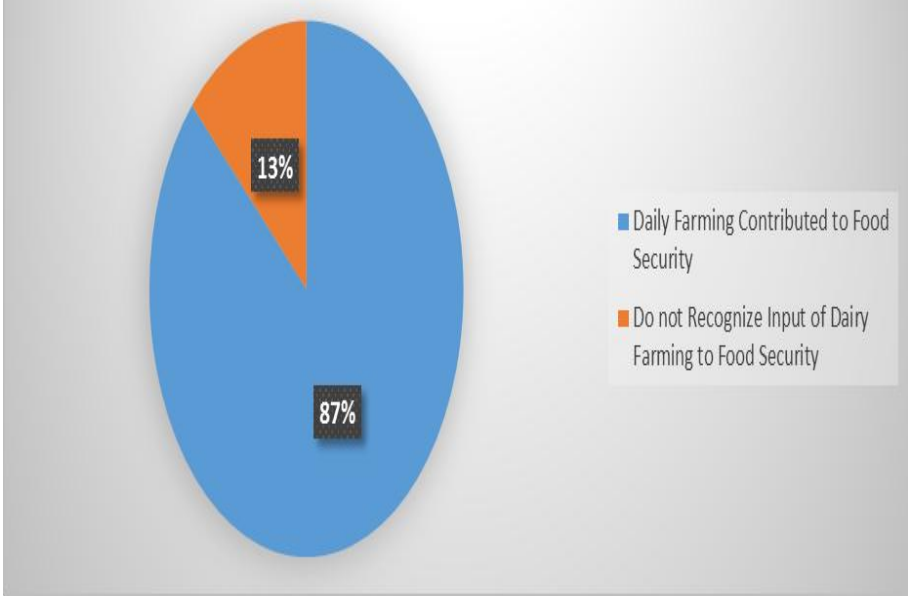

Figure 1: Dairy Farming Contribution to Food Security for Households

\section{Farm Inputs, Animal Feeds, and Veterinary Expenses}

Despite the fact that the farmers have made profits in their farming small-scale dairy farming in the sub-county has been experiencing challenges orchestrated by high costs of farm inputs and animal feeds. Farm inputs include those that are used in the growth of nippier grass and other animal feeds. Such inputs comprises of pesticides and fertilizers, which are used to ensure a constant supply of animal feeds. Their high costs make it difficult for smallscale dairy farmers to afford them in the recommended quantities, hence under production. There is also the high cost of animal feeds from manufacturing companies. The charges by the veterinary doctors also appeared to be extremely high, thus unaffordable to most of the farmers.

Addressing this challenge would require the government both at the local and at the national levels, to adopt some significant steps. One of the identifiable techniques, in this case, would be the provision of affordable loans to the farmers. This is significant to allow the farmers to borrow funds at little interest and repay at a convenient plan. Thus will enable the farmers to be in a position to purchase the necessary inputs or animal feed on a timely basis. The National government should devise tax policies that lead to subsidizing farm inputs and animal feeds that directly affect small-scale dairy farming. This will greatly lower the costs incurred in the rearing of dairy animals. In turn, this will give the farmers the ability to purchase the products or pay for veterinary expenses at an affordable price, and thereby raising their profits significantly. Therefore, the role of the government in achieving these goals is highly relevant, thus recommended.

\section{CONCLUSION AND RECOMMENDATION}

Conclusion: The study concludes that small-scale dairy farming has an effect in multiple ways on food security within the county. The effect is the provision of milk to the farmers for consumption as food. Small Scale dairy farmers use manures in the cultivation of food crops, thereby increasing crop yield. This means the farmers have enough food to feed their families, the local community, as well as sell to the outsiders. The result is high food production as well as the generation of cash through the sale of farm produce, thereby enabling farmers to buy other types of foods for a balanced diet. Thus small-scale dairy farming effect in ensuring food security.

Recommendation: Some of the critical steps that the national government may undertake offering tax waiver/reduction incentive to dairy farming inputs. This would lower the cost of milk production, thus maximizing profits earned by farmers. The National government could create policies that focus on improving the well-being of dairy farmers and dairy farming itself. Such policies may include laying down strategies for milk packaging, sale, etc. This would eliminate intermediaries in the chain, thus linking farmers directly to the market. The research recommendation was that the county government should intensify extension services, like veterinary services for 
Editon Consortium Publishing

Transforming Scholarly Publishing

\section{Editon Consortium Journal of Arts,} Humanities and Social Studies (ECJAHSS)

Doi: $10.51317 /$ ecjahss.v2i1.185

Volume: 02 Issue: 01 | Dec-2020

ISSN: $2663-8525$

Received: 02.12.2020; Accepted 05.12.2020; Published: 25.12.2020 at www.editoncpublishing.org

Mwangi, J.M., et al., Editon Cons. J. Arts., Humanit. S. Stud., Double -Blind Peer Reviewed Journal

better grades and disease control. The county government should invest in research activities that would enhance dairy farming practices. Such research activities may include those on the market, diseases, animal feeds, and value addition to dairy produce. Farmers are recommended to undertake simple financial records on the sale of milk.
They should also take the initiative to seek an extension and veterinary services available from the county government officers.

\section{References}

Bello, D. A. (2010). The Role of Cooperative Societies in Economic Development. Munich Personal RePEc Archive. Bruno, L., Georges, O., Hippolyte, A., and Midingoyi, S. (2015). Economic Welfare Change Attributable to Biological Control of Lepidopteran Cereal Stemborer Pests in East and Southern Africa: Cases of Maize and Sorghum in Kenya, Mozambique and Zambia. International Conference of Agricultural Economist. Milan, Italy: The University of Milan.

Clay, N., Garnett, T., \& Lorimer, J. (2019). Dairy intensification: Drivers, impacts and alternatives. Ambio, 49 (1), 35-48. Retrieved from doi: 10.1007/s13280-019-01177-y.

East Africa Dairy Development Project (2013). International Livestock Research Institute. Nairobi, Kenya.

FAO. (2020). The State of Food and Agriculture 2019. Food and Agriculture Organization.

Kibiego, M. B., Lagat, J. K., \& Bebe, B.O. (2015). Assessing the Economic Efficiency of Dairy Production Systems

in Uasin Gishu County, Kenya. Journal of Economics and Sustainable Development, 146-153.

Ministry of Agriculture is National Dairy Development Policy, (2013). Sessional Paper no 5 on National Dairy Policy of 2013.

Njiru, R. (2015). Effects of Dairy Cooperatives on Incomes of Smallholder Dairy Farmers: A Case Study of Mkulima Bora Dairy Cooperative in Embu County, Kenya. The Journal of Agriculture and Science.

Nyarongi, O. J. (2003). Antimicrobial resistance in eshcherichia coli isolates from feaces and carcass samples of slaughtered cattle, swine and chicken in Kenya.

Nyoike, E. (2015). Radio and small-scale farming in Murang'a: A study of Mugambo wa Murimi program in Inooro FM. Nairobi, Kenya: University of Nairobi.

Omolo, M. W. (2012). The impact of trade liberalization on Poverty levels in Kenya. Retrieved fromAmicrosimulation.https://www.gtap.agecon.purdue.edu/resources/download/5699.pdf.

Rademaker, C., Bebe, B., Lee, J., Kilelu, C., \& Tonui, C. (2016). Sustainable growth of the Kenyan dairy sector. Wageningen, Netherlands: Wageningen University \& Research.

Richards, S., VanLeeuwen, J., Shepelo, G., Gitau, G., Kamunde, C., Uehlinger, F., \& Wichtel, J. (2015). Associations of farm management practices with annual milk sales on smallholder dairy farms in Kenya. Veterinary World, 8(1), 88-96. Retrieved from doi: 10.14202/vetworld.2015.88-96.

URT, (2001). Agricultural Sector Development Strategy, Ministry Of Agriculture Dar-es-Salaam, Tanzania

World Bank. (2019). Ending Poverty, Investing in Opportunity. World Bank Report 2019. 